\title{
PENETAPAN BATAS HUTAN PRODUKSI TERBATAS (HPT) DI DESA TURUNGAN BAJI KECAMATAN SINJAI BARAT
}

\author{
Rahmatullah $^{1}$, Mappamiring ${ }^{2}, \mathbf{A b d i}^{3}$ \\ 1) Jurusan Ilmu Administrasi Negara Unismuh Makassar \\ 2) Jurusan Ilmu Administrasi Negara Unismuh Makassar \\ 3) Jurusan Ilmu Administrasi Negara Unismuh Makassar
}

\begin{abstract}
The object of this research is to know the communication interlaced between the society of Turungan Baji village and the government of Sinjai regency-the environment and forestry department of Sinjai regency-within Border Determining of Production Forest Restricted in Turungan Baji village, sub-district west Sinjai. The method applied in this research is descriptive-qualitative approach. This research involves twelve informants. The technique of data collecting is observation, interview, and documentation which implemented directly by researcher. The result of this research demonstrates that Border Determining of Production Forest Restricted involves society in planning and pointing, but not all of them. An inhibitory factor in Border Determining of Production Forest Restricted is less of socialization of government toward the society of Turung Baji, whereas the supporting factor is to give society clarity about forest which has to be saved.
\end{abstract}

Key word: Border Determining of Production Forest Restricted

\begin{abstract}
ABSTRAK
Penelitian ini bertujuan untuk mengetahui komunikasi yang terjalin antara masyarakat Desa Turungan Baji dan Pemerintah Daerah Kabupaten Sinjai dalam hal ini Dinas Lingkungan Hidup dan Kehutanan Kabupaten Sinjai dalam Penetapan Batas Hutan Produksi Terbatas (HPT) di Desa Turungan Baji Kecamatan Sinjai Barat. Metode yang digunakan dalam penelitian ini adalah pendekatan deskripsi kualitatif. Informan dalam penelitian ini adalah sebanyak 12 orang. Teknik pengumpulan data dalam penelitian ini adalah observasi, wawancara dan dokumentasi yang dilakukan secara langsung oleh peneliti. Hasil penelitian mengenai Penetapan Batas Hutan Produksi Terbatas (HPT) di Desa Turungan Baji Kecamatan Sinjai Barat menunjukkaan bahwa proses Penetapan Batas Hutan Produksi Terbatas (HPT) melibatkan Masyarakat berpartisipasi dalam perencanaan ataupun penunjukan, tetapi tidak keseluruhan masyarakat. Faktor Penghambat dalam Penetapan Batas Hutan Produksi Terbatas (HPT) Rendahnya sosialisasi yang dilakukan oleh pihak pemerintah kepada masyarakat Desa Turungan Baji. Faktor pendukung dalam Penetapan Batas Hutan Produksi Terbatas (HPT) di Desa Turungan Baji Kecematan Sinjai Barat adalah dengan adanya tapal batas. Dengan adanya tapal batas hutan produksi terbatas (HPT) memberi kejelasan kepada masyarakat mengenai batas hutan yang bisa di kelolah ataupun dilindungi.
\end{abstract}

Kata kunci: Penetapan Batas Hutan Produksi Terbatas (HPT) 


\section{PENDAHULUAN}

Penyelenggaraan kehutanan bertujuan untuk sebesar-besar kemakmuran rakyat yang berkeadilan dan berkelanjutan dengan menjamin keberadaan hutan dengan luasan yang cukup dan sebaran yang proporsional; mengoptimalkan aneka fungsi hutan yang meliputi fungsi konservasi, fungsi lindung, dan fungsi produksi untuk mencapai manfaat lingkungan, sosial, budaya, dan ekonomi, yang seimbang dan lestari; meningkatkan daya dukung daerah aliran sungai; meningkatkan kemampuan untuk mengembangkan kapasitas dan keberdayaan masyarakat secara partisipatif, berkeadilan, dan berwawasan lingkungan sehingga mampu menciptakan ketahanan sosial dan ekonomi serta ketahanan terhadap akibat perubahan eksternal; dan menjamin distribusi manfaat yang berkeadilan dan berkelanjutan. (Pasal 3 Undang-Undang RI no 41/1999 tentang kehutanan).

Masalah penetapan batas Penetapan Batas Hutan Produksi Terbatas (HPT) sudah sangat marak terjadi tak terkecuali di Desa
Turungan Baji Kecamatan Sinjai Barat. Kriminalisasi yang marak dirasakan warga karena mempertahankan tanahnya yang diklaim oleh Dinas Lingkungan hidup dan Kehutanan Kabupaten Sinjai sebagai kawasan hutan produksi terbatas sangat bertentangan dengan (UndangUndang RI No 41/1999 tentang kehutanan). Sehingga Komunikasi antar pemerintah Daerah dalam hal ini Dinas Lingkungan Hidup dan Kehutanan Kabupaten Sinjai dengan Masyarakat Desa Turungan Baji Kecematan SinjaiBarat perlu menjalin komunikasi yang lebih baik lagi sebagaimana tujuan dari komunikasi komunikasi adalah menciptakan pemahaman bersama atau mengubah persepsi, bahkan perilaku (Riant Nugroho 2004).

Untuk dapat memahami hakikat suatu komunikasi perlu diketahui prinsip dari komunikasi tersebut, ada empat prinsip dasar dari komunikasi yaitu: Suatu proses, suatu sistemik, interaksi dan transaksi, dimaksudkan atau tidak dimaksudkan. Soiler dalam (Arni Muhammad 2005). 
Kemunikasi sebagai proses menciptakan dan saling menukar pesan dalam suatu jaringan hubungan yang saling tergantung satu sama lain untuk mengatasi Lingkungan yang tidak pasti atau yang selalu berubahubah, Goldhaber (Syahdan T, Hasrul. 2015).

$$
\text { Komunikasi yang }
$$
menentukan alternatif apa yang ada dalam suatu pengambilan keputusan tertentu, melaksanakan kekuasaan. Orang-orang yang terlibat dalam tatanan semacam ini akan merasa bahwa ada demokrasi di tempat mereka bekerja, Block dalam (Syahdan T, Hasrul. 2015).

Komunikasi dipandang dari suatu perspektif interpretatif (subjektif) adalahproses penciptaan makna atas interaksi yang merupakan komunikasi. Konsep makna adalah relefan dan penting untuk membedakan antara objektif dan subjektif Mengenai komunikasi (Cangara, 2007).

Komunikasi yang efektif
adalah penting bagi semua
organisasi. Oleh karena itu, para
pemimpin organisasi dan para
komunikan dan para komunikator

dalam organisasi perlu memahami dan menyempurnakan kemampuan komunikasi mereka, Kohler dalam (Dr. Arni Muhammad 2014)

Komunikasi sebagai proses pertukaran informasi antara dua orang atau lebih, dan dalam proses itu terjadi kegiatan-kegiatan memberi atau mengirim, menerima dan menanggapi pesan-pesan diantara orang-orang yang berintraksi. Proses pertukaran informasi antara dua orang atau lebih, dalam kegiatan tersebut terjadi pertukaran informasi. Erlina (2005).

Komunikasi pemerintahan adalah penyampaian ide, program dan gagasan pemerintah kepada masyarakat dalam rangka mencapai tujuan negara. Namun dalam suasana tertentu bisa sebaliknya pemerintah berada pada posisi mencermati apa yang diinginkan masyarakat. (Erlina, Hasan, 2005).

Berger, dalam (Syahdan T, Hasrul. 2015). merumuskan tugas pokok komunikasi dalam suatu perubahan sosial dalam rangka pembangunan nasional, yaitu: 1.Menyampaikan kepada masyarakat, informasi tentang 
pembangunan nasional, agar mereka memusatkan perhatian pada kebutuhan akan perubahan, kesempatan dan cara mengadakan perubahan, dan membangkitkan aspirasi nasional. 2. Memberikan kesempatan kepada masyarakat untuk mengambil bagian secara aktif dalam proses pembuatan keputusan, memperluas dialog agar melibatkan semua pihak yang akan membuat keputusan mengenai perubahan, memberi kesempatan kepada para pemimpin dan mendengarkan pendapat rakyat kecil, dan menciptakan arus informasi yang berjalan lancar dari bawah keatas. 3.Mendidik tenaga kerja yang diperlukan pembangunan, sejak orang dewasa hingga anak-anak, sejak pelajaran baca tulis hingga keterampilan teknis yang mengubah hidup masyarakat.

Partisipasi dapat diartikan sebagai sumbangan, keterlibatan keikutsertaan warga masyarakat dalam berbagai kegiatan pembangunan, Oakley dalam (Syahdan T, Hasrul. 2015).

$$
\text { Partisipasi masyarakat }
$$
sebagai proses komunikasi dua arah yang terus menerus dapat diartikan bahwa partisipasi masyarakat merupakan komunikasi antara pihak pemerintah sebagai pemegang kebijakan dan masyarakat di pihak lain sebagai pihak yang merasakan langsung dampak dari kebijakan tersebut, Canter dalam dalam (Syahdan T, Hasrul. 2015). Dari pendapat Canter juga tersirat bahwa masyarakat dapat memberikan respon positif dalam artian mendukung atau memberikan masukan terhadap program atau kebijakan yang diambil oleh pemerintah, namun dapat juga menolak kebijakan.

Partisipasi sebagai kesediaan untuk membantu keberhasilan setiap program sesuai dengan kemampuan setiaporangtanpamengorbankankepe ntingandirisendiri, Mubyarto dalam (Syahdan T, Hasrul. 2015).

Kebijakan publik merupakan pilihan apapun oleh pemerintah, baik untuk melaksanakan sesuatu maupun untuk tidak melaksanakan sesuatu. Dye (dalam Andi pradana pandi 2016).

Menurut Jones yang dikutip Tangkilisan, dalam Nuryanti Mustari 
2013:63) kebijakan terdiri dari komponen-komponen yaitu : 1.Goal atau tujuan yang diinginkan. 2. Plans atau proposal, yaitu pengertian yang spesifik untuk mencapai tujuan. 3.Programs, yaitu upaya yang berwenang untuk mencapai tujuan. 4.Decision atau keputusan, yaitu tindakan-tindakan untuk menentukan tujuan, membuat rencana, melaksanakan dan mengevaluasi program. 5. Effects, yaitu akibatakibat dari program (baik disengaja atau tidak, primer atau sekunder.

Penetapan adalah tindakan pemerintahan dalam jabatan, yang secara sepihak dan disengaja dalam suatuikhwal tertentu, menetapkan suatu hubungan hukum atau keadaan hukum yang sedang berjalan atau menimbulkan suatu hubungan hukum atau keadaan hukum baru, atau menolak salah satu yang dimaksud, A.M. Donner dalam (Syahdan T, Hasrul. 2015).

Masyarakat Adat adalah komunitas-komunitas yang Hidup berdasarkan asal-usul leluhur secara turun temurun diatas suatu wilayah adat, yang memiliki kedaulatan atas tanah dan kekayaan alam, keHidupan sosial budaya, yang diatur oleh hukum adat dan lembaga adat yang mengelolah keberlangsungan kehidupan masyarakatnya. Sumber Aliansi Masyarakat Adat Nusantara (AMAN).

Peran serta masyarakat berdasarkan undang-undang Nomor 41 tahun 1999 tentang Kehutanan BAB X pasal 69 ayat (1) Masyarakat berkewajiban untuk ikut serta memelihara dan menjaga kawasan hutan dari gangguandan perusakan. (2) Dalam melaksanakan rehabilitasi hutan, masyarakat dapat meminta pendampingan pelayanan, dan dukungan kepada lembaga swadaya masyarakat, pihak lain, atau pemerintah. Pasal 70 ayat (1) Masyarakat turut berperan serta dalam pembangunan di bidang Kehutanan. (2) Pemerintah wajib mendorong peran serta masyarakat melalui berbagai kegiatan di bidang Kehutanan yang berdaya guna dan berhasil guna. (3) Dalam rangka meningkatkan peran serta masyarakat Pemerintah dan Pemerintah Daerah dapat dibantu oleh forum pemerhati Kehutanan. (4) Ketentuan lebih lanjut 
sebagaimanadimaksud pada ayat (1) dan ayat (2) diatur dengan peraturan pemerintah.

(Undang-Undang

Republik Indonesia Nomor 41 Tahun 1999 Tentang Kehutanan).

Deskripsi fokus dalam penelitian ini yaitu:Pemahaman bersama, bagaimana proses komunikasi yang terjaling antar Dinas Lingkungan Hidup dan Kehutanan Kabupaten Sinjai kepada masyarakat dalam mencapai kata sepakat, sependirian dan setuju dalam Penetapan Batas Hutan Produksi Terbatas (HPT) di Desa Turungan Baji; Persamaan persepsi merupakan suatu tindakan menyusun, mengenali dan menafsirkan informasi guna memberikan gambaran dan pemahaman tentang Penetapan Batas Hutan Produksi Terbatas (HPT); Perilaku, bagaimana tindakan Dinas Lingkungan Hidup dan Kehutanan Kabupaten Sinjai dalam Penetapan Batas HutanProduksiTerbatas (HPT). Serta bagaimana respon masyarakat terhadap proses Penetapan Batas HutanProduksiTerbatas

(HPT);Faktor Penghambat dalam Penetapan Batas Hutan Produksi
Terbatas (HPT). Dengan melihat Pemahaman bersaman, persamaan persepsi bahkan perilaku antara Dinas Lingkungan Hidup dan Kehutanan Kabupaten Sinjai dengan Masyarakat Desa Turungan Baji; Faktor pendukung dalam Penetapan Batas Hutan Produksi Terbatas (HPT), dengan melihat Pemahaman bersaman, persamaan persepsi bahkan perilaku antara Dinas Lingkungan Hidup dan Kehutanan Kabupaten Sinjai dengan Masyarakat Desa Turungan Baji.

\section{METODE PENELITIAN}

Waktu yang dilakukan dalam penelitian ini adalah dua bulan dimulai pada tanggal 13 Februari sampai dengan 13 April.Adapun lokasinya yaitu di Dinas Lingkungan Hidup dan KehutananKabupaten Sinjai, Aliansi Masyarakat Adat Nusantara dan Masyarakat Adat Desa Turungan Baji Kecematan SinjaiBarat. Dengan alasan dan pertimbangan bahwa perlu dikomunikasikan mengenai penetapan kawasan hutan produksi terbatas (HPT) di kabupaten Sinjai. Dengan menggunakan jenis dan tipe 
penelitian. Jenis Penelitian yang digunakan dalam penelitian adalah kualitatif yaitu mengkaji objek dan mengungkapkan

fenomenafenomena yang ada dan memberikan gambaran ataupun penjelasan yang berkaitan dengan judul penelitian. Tipe Penelitian yang digunakan dalam penelitian ini studi kasus, yaitu merupakan bentuk penelitian yang meneliti penomena khusus yang hadir dalam suatu konteks yang terbatasi (bounded context).

Adapun Informan penelitian ini adalah Kepala Seksi Tahura Dinas Lingkungan Hidup dan Kehutanan, Polisi Kehutanan Dinas Lingkungan Hidup dan Kehutanan, Aliansi Masyarakat Adat Nusantara, Kepala Desa, Tokoh Masyarakat, Pemuda Adat Turungan dan Masyarakat. Data penelitian diperoleh melalui observasi, wawancara, dan dokumentasi. Teknik analisis data dilakukan dengan cara reduksi data, penyajian data, dan penarikan kesimpulan dan verifikasi. Keabsahan data menggunakan teknik triangulasi yang berjenis triangulasi sumber, triangulasi teknik, dan triangulasi waktu.

\section{HASIL DAN PEMBAHASAN}

Berdasarkan dengan tujuan penelitian ini yang tercantum pada bab sebelumnya, yaitu, untuk Untuk mengetahui proses Penetapan Batas Hutan Produksi Terbatas (HPT) di Desa Turungan Baji Kecamatan Sinjai Barat.

Untuk mengetahui faktor penghambat dan faktor pendukung Penetapan Batas Hutan Produksi Terbatas (HPT) di Desa Turungan Baji Kecamatan Sinjai Barat.

Penetapan Batas Hutan Berdasarkan perencanaan sesuai dengan undang-undang nomor 41 tahun 1999 tentang Kehutanan. Perubahan peruntukan dan fungsi kawasan hutan ditetapkan oleh Pemerintah dengan didasarkan pada hasil penelitian terpadu. Pasal 19 Ayat (1) Undang-undang No 41 Tahun 1999.

$$
\begin{aligned}
& \text { Undang-undang Kehutanan } \\
& \text { juga mengatur kategori hutan } \\
& \text { berdasarkan fungsinya. Fungsi hutan } \\
& \text { menurut Undang-undang Kehutanan } \\
& \text { dibagi tiga, yaitu konservasi, lindung, } \\
& \text { dan produksi. Penetapan fungsi hutan }
\end{aligned}
$$


berkaitan erat dengan aturan untuk pemanfaatannya. Sehingga, dapat disimpulkan bahwa penetapan dan penamaan hutan akan membawa dua status nama sekaligus, yaitu nama pengelolanya dan fungsinya. Sebagai contoh, hutan adat produksi.

Dalam proses penetapan hutan, terlebih dahulu dimulai dari proses penetapan suatu kawasan hutan oleh Pemerintah. Pemerintah yang berwenang melakukan penetapan hutan adalah Kementerian Kehutanan (atau sekarang disebut Kementerian Kehutanan dan Lingkungan Hidup). Sebagai Pemerintah yang berwenang melakukan pengurusan terhadap hutan, ada empat hal yang dilakukan yaitu perencanaan kehutanan, pengelolaan kehutanan, penelitian dan sosialisasi, dan pengawasan. Dikarenakan bahasan kali ini fokus terhadap penetapan hutan, maka yang hanya dijabarkan lebih lanjut mengenai perencanaan kehutanan saja pasal 11 ayat (2) Undang-undang No 41 Tahun 1999.

Perencanaan kehutanan merupakan proses yang terdiri dari beberapa hal, yaitu: inventarisasi hutan, pengukuhan kawasan hutan, penatagunaan kawasan hutan, pembentukan wilayah pengelolaan hutan, dan penyusunan rencana kehutanan.

$$
\text { Dalam menjalankan tugas }
$$

Dinas Lingkungan Hidup dan Kehutanan Kabupaten Sinjai Sebagai Pemerintah yang berwenang melakukan pengurusan terhadap hutan, ada empat hal yang dilakukan yaitu: inventarisasi hutan, pengukuhan kawasan hutan, penatagunaan kawasan hutan, pembentukan wilayah pengelolaan hutan, dan penyusunan rencana kehutanan. 1. Inventarisasi hutan merupakan sarana untuk mengetahui dan memperoleh data dan informasi tentang sumber daya, potensi kekayaan alam hutan, serta lingkungannya secara lengkap. Inventarisasi ini dilakukan dengan mengetahui status dan keadaan fisik hutan, flora dan fauna, sumber daya manusia, serta kondisi sosial masyarakat di dalam dan di sekitar hutan. Hasil inventarisasi inilah yang digunakan oleh Dinas Lingkungan Hidup dan Kehutanan Kabupaten Sinjai sebagai dasar pengukuhan kawasan hutan bahkan sistem 
informasi kehutanan. 2. Pengukuhan kawasan hutan didasarkan dari hasil inventarisasi hutan. Proses pengukuhan kawasan hutan itu melalui tahapan penunjukan kawasan hutan, penataan batas kawasan hutan, pemetaan kawasan hutan, dan penetapan kawasan hutan.Dinas Lingkungan Hidup dan Kehutanan Kabupaten Sinjai dalam melakukanpengukuhan kawasan hutan juga memperhatikan rencana tata ruang wilayah yang ada. 3 . Setelah melalui pengukuhan kawasan hutan, diselenggarakanlah penatagunaan kawasan hutan. Penatagunaan kawasan hutan meliputi kegiatan penetapan fungsi dan penggunaan kawasan hutan.

$$
\text { Kegiatan penatagunaan }
$$

kawasan dan penetapan fungsihutan yang berada di Desa Turungan Baji Kecematan SinjaiBarat di lakukan oleh pihak kehutanan kabupaten Sinjai yang ditugaskan dalam wilayah administrasi Kecematan SinjaiBarat lebih tepatnya di Desa Turungan Baji. 4. Wilayah pengelolaan hutan dilaksanakan dengan tingkat-tingkat tertentu, yaitu: provinsi, kabupaten/kota, dan unit pengelolaan. Pembentukan wilayah pengelolaan hutan ini tentulah harus memperhatikan keberadaan masyarakat hukum adat selain faktorfaktor menentukan lainnya. Berdasarkan Pasal 34 dan 67 Undang-undang Republik Indonesia Nomor 41 tentang Kehutanan masyarakat hukum adat dapat mengelola hutan.

$$
\text { Pembentukan wilayah }
$$
pengelolaan hutan yang berada diDesa Turungan Baji yang menjadi kendala ataupun sebagai faktor penghambat dalam Penetapan Batas Hutan Produksi Terbatas (HTP), karena masyarakat Desa Turungan Baji pada saat ini sedang memperjuangkan pengakuan dirinya sebagai masyarakat Adat yang didukung oleh Peraturan Daerah Kabupaten Sinjai yang telah disusun oleh Aliansi Masyarakat Adat Nusantara Sinjai (AMAN) dengan DPRD Kabupaten Sinjai yang pada saat ini menunggu persetujuan dan penandatanganan oleh Bupati Sinjai.

5. Setelah melalui semua tahapan diatas, Pemerintah menyusun rencana kehutanan yang diatur melalui Peraturan Pemerintah secara spesifik. 
Mengenai kewenangan Pemerintah (Kementerian Kehutanan) dalam penetapan kawasan hutan, melalui Putusan MK No. 45/PUU-IX/2011 dinyatakan bahwa hal tersebut tidak dapat serta merta dilakukan hanya berdasarkan penunjukan sepihak dari pihak Pemerintah (Pasal 1 angka 3 Undang-Undang tentang Kehutanan). MK membatalkan Pasal 1 angka 3 UU Kehutanan sepanjang frase "ditunjuk dan/atau". Ini artinya penetapan kawasan hutan harus melalui tahapan-tahapan yang dipersyaratkan dan melibatkan partisipasi publik terutama dalam informasi kehutanan yang ada.

Mengenai prosedur penetapan hutan secara spesifik, sejauh yang kami masyarakat Desa Turungan Baji memperhatikan Penetapan Batas Hutan Produksi Terbatas (HTP) masih belum memiliki kejelasan mekanisme dan tata caranya selain daripada kewenangan Kementerian Kehutanan untuk menetapkan hutan.

Untuk itu sebagai Masyarakat perlu kajian bahasan dan kajian lebih lanjut untuk memberikan tindak lanjut penetapan hutan adat sebagai mandat Putusan MK No.
35.Berdasarkan Undang-Undang Nomor 41 tahun 1999 Pasal 3 huruf (d) dan (e) tentang kehutanan. Penyelenggaraan kehutanan bertujuan untuk sebesar-besar kemakmuran rakyat yang berkeadilan dan berkelanjutan dengan: (d) meningkatkan kemampuan untuk mengembangkan kapasitas dan keberdayaan masyarakat secara partisipatif, berkeadilan, dan berwawasan lingkungan sehingga mampu menciptakan ketahanan sosial dan ekonomi serta ketahanan terhadap akibat perubahan eksternal; dan (e) menjamin distribusi manfaat yang berkeadilan dan berkelanjutan.

$$
\text { Penetapan Batas Hutan }
$$

Produksi Terbatas (HPT) di Desa Turungan Baji Kecematan SinjaiBarat. Penelitian ini dapat dikembangkan berdasarkan teori Dr. Riant Nugroho (2004) tujuan komunikasi adalah menciptakan pemahaman bersama atau mengubah persepsi, bahkan perilaku.Seperti berikut: 1. Komunikasi bertujuan untuk menciptakan pemahaman bersama baik dari pihak Dinas Lingkungan Hidup dan Kehutanan Kabupaten Sinjai maupun dari 
Masyarakat DesaTurungan Baji belum tercapai secara efektif, hal ini dapat dilihat dengan permasalahan yang di temui peneliti pada masyarakat DesaTurungan Baji.

Dinas Lingkungan Hidup dan Kehutanan Kabupaten Sinjai disampaikan apa tujuan Hutan Produksi Terbatas (HTP) ditetapkan pemerintah menginginkan ada kejelasan antara wilayah kelolah kebun masyarakat dengan wilayah hutan negara ada kejelasan, sehingga areal hutan negara ini dapat kita jaga dan awasi bersama masyarakat dapat ikut serta dalam pengawasan hutan produksi terbatas.Berdasarkan

Pemahaman berasal dari kata paham yang artinya (1) pengertian; pengetahuan yang banyak, (2) pendapat, pikiran, (3) aliran; pandangan, (4) mengerti benar (akan); tahu benar (akan); (5) pandai dan mengerti benar. Apabila mendapat imbuhan me- i menjadi memahami, berarti : (1) mengerti benar (akan); mengetahui benar, (2) memaklumi. dan jika mendapat imbuhan pe- an menjadi pemahaman, artinya (1) proses, (2) perbuatan, (3) cara memahami atau memahamkan mempelajari baik-baik supaya paham (Depdikbud, 1994).

$$
\text { Kepala Desa Turungan Baji }
$$
memaparkan kepada peneliti bahwa sanya dapat dimengerti masksud dan tujuan pemerintah daerah kabupaten Sinjai menetapkan batas Hutan Produksi Terbatas(HPT), hanya saja masyarak yang ada di Desa Turungan Baji kurang terlibat dalam penetapan batas hutan produksi terbatas tersebut. Karena hanya sebahagian masyarakat yang terlibat dalam membantu pemerintah dalam proses penetapan tapal batas,yang dilibatkan hanya kepala dusun dan kepala Desa pada waktu itu. Padahal partisipasi masyarakat harusnya berperan penting dalam suatu kegiatan, kebijakan pemerintah, Berdasarkan

Pemerintahdapatmenyampaika $\mathrm{n}$ ide, program dan gagasan pemerintah kepada masyarakat dalam rangka mencapai tujuan negara. namun dalam suasana tertentu bisa sebaliknya pemerintah berada pada posisi mencermati apa yang diinginkan masyarakat. (Erlina, Hasan, 2005). 2. Masalahan yang terjadi dalam Penetapan Batas Hutan Produksi Terbatas (HPT) di 
DesaTurungan Baji Kecematan SinjaiBarat. Disebabkan oleh tidak dilibatkan masyarakat secara keseluruhan berpartisipasi, rendahnya sosialisasi dari pemerintah daerah dalam hal ini Dinas Lingkungan Hidup dan Kehutanan Kabupaten Sinjai kepada masyarakat dalam Penetapan Batas Hutan Produksi Terbatas (HPT) di DesaTurungan Baji, serta sebahagian wilayah kebun masyarakat di klaim sebagai kawasan Hutan Produksi Terbatas (HPT).

Pemuda adat menberikan pernyataan bahwa dalam setiap perencanaan pelaksanaan kegiatan penetapan ataupun penunjukan dalam pengelolaan Hutan Produksi Terbatas (HPT), pihak pemerintah kabupaten Sinjai maupun pemerintah Desa Turungan Baji kecematan SinjaiBarat tidak melibatkan kami di dalam rapat untuk memberikan suatu masukan atau ide-ide guna menunjang program yan ingin di capai. Padahal partisipasi masyarakat memiliki peran yang sangat penting dalang keberlangsungan suatu kebijakan ataupun peraturan yang di keluarkan oleh pemerintah.

Sementara partisipasi dapat diartikan sebagai sumbangan, keterlibatan keikutsertaan warga masyarakat dalam berbagai kegiatan pembangunan, Oakley dalam (Syahdan T, Hasrul. 2015). 3.Ditinjau dari segi perilaku masyarakat dalam Penetapan Batas Hutan Produksi Terbatas (HPT), masyarakat secara jelas menolak adanya Penetapan Batas Hutan Produksi Terbatas (HPT) di DesaTurungan Baji sebab dalam penetapan tapal batas tersebut dari pihak kehutanan banyak memasukkan wilaya kelolah kebun masyarakat sebagai kawasan Hutan Produksi Terbatas (HPT).

Ketua bidang pengelolaan taman hutan rakyat (Tahura) di Dinas Lingkungan Hidup dan Kehutanan kabupaten Sinjai pada tanggal 28 februari 2017 menyatakan bawa Penetapan Batas Hutan Produksi Terbatas (HPT) di kecematan SinjaiBarat terkhusus Hutan Produksi Terbatas (HPT) yang ada di DesaTurungan Baji pertama kali di tetapkan pada tahun 1982 yang 
kemudian di tetapkan kembali pada tahun 1994. Sebelum Hutan Produksi Terbatas (HPT) di DesaTurungan Baji terlebih dahulu dilakukan pengukuran oleh polisi kehutanan guna penempatan tapal batas kawasan hutan. Proses pengukuran tersebut melibatkan Kepala Desa dan Kepala Dusun yang ada di DesaTurungan Baji dalam menetapka tapal batas atau patok. Lain halnya dengan pernyataan tokoh masyarakat Adat Desa Turungan Baji Kecematan SinjaiBarat, bahwa masyarakat yang bermukim di DesaTurungan Baji menolak pemetaan yang dilakukan oleh Dinas Perkebunan dan Kehutanan yang sekarang dinas lingkungan hidup dan kehutanan Kabupaten Sinjai, Sebab pemetaan Hutan Produksi Terbatas (HPT). yang dilakukan oleh kehutanan banyak memasukkan wilayah perkebunan yang di kelolah oleh masyarakat, Lahannya yang telah ditanaminya dengan tanaman produktif seperti cengkeh, kopi, coklat dan tanaman lainya, telah di klaim sebagai Hutan Produksi Terbatas (HPT).
Komunikasi sangatlah penting dalam menentukan alternatif apa yang ada dalam suatu pengambilan keputusan tertentu, melaksanakan kekuasaan. Orangorang yang terlibat dalam tatanan semacam ini akan merasa bahwa ada demokrasi di tempat mereka bekerja, Block dalam (Romli Khomsahrial 2011).

Dinas Lingkungan Hidup dan Kehutanan penempatan batas Hutan Produksi Terbatas (HPT) yang ada di DesaTurungan Baji mengenai masalah penempatan tapal batas kawasan hutan Hutan Produksi Terbatas (HPT) sudah sangat jelas hanya saja dalam proses penempatan tapal batas tersebut hanya melibatkan kepala Desa dan kepala dusun tampa melibatkan masyarakat adat sekitar dan proses penempatan tapal batas yang boleh dikatakan kurang akurat. Yang mengakibatkan lahirnya penolakan deri berbagai elemen masyarakat tentang penunjukan tapal batas dan penetapan batas Hutan Produksi Terbatas (HPT) yang ada di Desa Turungan Baji.Komunikasi kebawah adalah untuk menyampaikan tujuan, untuk 
merubah sikap, membentuk (HPT) yang dilakukan oleh pendapat, mengurangi ketakutan dan kecurigaan yang timbul karena salah informasi, mencegah kesalah pahaman karena kurang informasi dan mempersiapkan anggota organisasi untuk menyesuaikan diri dengan perubahan, Lewis dalam (Arni, Muhammad, 2014). Dan sekiranya ada juga komunikasi dari bawah keatas yang berfungsi sebagai balikan bagi pemipin memberikan petunjuk tentang keberhasilan suatu pesan yang disampaikan kepada bawahan dan dapat memberikan stimulus kepada karyawan untuk berpartisipasi dalam merumuskan kebijakan pelaksanaan kebijakan bagi departemennya atau organisasinya, menurut Smith dalam (Arni, Muhammad, 2014).

Tokoh masyarakat Adat Desa Turungan Baji Kecematan Sinjai Barat, mengatakan bahwa hampir semua masyarakat yang bermukim di DesaTurungan Baji menolak sistem pemetaan yang dilakukan oleh Dinas Perkebunan dan Kehutanan yang sekarang dinas lingkungan hidup dan kehutanan Kabupaten Sinjai, Sebab pemetaan Hutan Produksi Terbatas kehutanan banyak memasukkan wilayah perkebunan yang di kelolah oleh masyarakat, lahannya yang telah ditanaminya dengan tanaman produktif seperti cengkeh, kopi, coklat dan tanaman lainya, telah di klaim sebagai Hutan Produksi Terbatas (HPT).

Sumodingrat

Gunawan 2012.Partisipasi sebagai salah satu elemen pembangunan merupakan proses adaptasi masyarakat terhadap perubahan yang sedang berjalan. Dengan demikian partisipasi mempunyai posisi yang penting dalam pembangunan.

Masyarakat menolak karena
tidak sesuai dengan hal-hal
perencanaan kehutanan seperti
Inventarisasi hutan merupakan sarana
untuk mengetahui dan memperoleh
data dan informasi tentang sumber
daya, potensi kekayaan alam hutan,
serta lingkungannya secara lengkap.
Inventarisasi ini dilakukan dengan
mengetahui status dan keadaan fisik
hutan, flora dan fauna, sumber daya
manusia, serta kondisi sosial
masyarakat di dalam dan di sekitar
hutan. Hasil inventarisasi inilah yang


akan digunakan sebagai dasar pengukuhan kawasan hutan bahkan sistem informasi kehutanan.

$$
\text { Partisipasi masyarakat }
$$

sebagai proses komunikasi dua arah yang terus menerus dapat diartikan bahwa partisipasi masyarakat merupakan komunikasi antara pihak pemerintah sebagai pemegang kebijakan dan masyarakat di pihak lain sebagai pihak yang merasakan langsung dampak dari kebijakan tersebut, Canter dalam (Syahdan T, Hasrul. 2015). Dari pendapat Canter dalam (Arimbi. 2004).

$$
\text { Juga tersirat bahwa }
$$

masyarakat dapat memberikan respon positif dalam artian mendukung atau memberikan masukan terhadap program atau kebijakan yang diambil oleh pemerintah, namun dapat juga menolak kebijakan. Kemunikasi sebagai proses menciptakan dan saling menukar pesan dalam suatu jaringan hubungan yang saling tergantung satu sama lain untuk mengatasi Lingkungan yang tidak pasti atau yang selalu berubah-ubah, Goldhaber dalam (Fajar Junaedi, 2012).

\section{KESIMPULAN}

Berdasarkan hasil penelitian yang dilakukan di Dinas Lingkungan Hidup dan KehutananKabupaten Sinjai, Aliansi Masyarakat Adat Nusantara dan Masyarakat Adat Desa Turungan Baji Kecamatan Sinjai Barat. Penetapan batas hutan produksi terbatas (HPT) yang dilakukan oleh pemerintah dalam hal ini dinas lingkungan hidup dan kehutanan kabupaten Sinjai tergolong kurang efektif dalam pencapaian hasil penetapan batas hutan produksi terbatas (HPT) karena kurang sesuai dengan peraturan perundang undangan yang berlaku.

Faktor Penghambat dalam Penetapan Batas Hutan Produksi Terbatas (HPT) di Desa Turungan Baji Kecematan SinjaiBarat. Di pengaruhi oleh beberapa faktor seperti. (1) Rendahnya sosialisasi yang dilakukan oleh pihak pemerintah. (2) kurangnya pengetahuan masyarakat desa turungan baji tentang penetapan Batas Hutan Produksi Terbatas (HPT) maupun tujuan tapal batas yang ada. (3) Masyarakat kurang 
dilibatkan berpartisipasi dalam penetapan Batas Hutan Produksi Terbatas (HPT). (4) Masyarakat di Desa Turungan Baji Kecematan SinjaiBarat masih mengklain dirinya sebagai masyarakat adat. Sedangkan Faktor pendukung dalam Penetapan Batas Hutan Produksi Terbatas (HPT) di Desa Turungan Baji Kecematan SinjaiBarat. Di dukung oleh beberapa faktor seperti. (1) Dengan adanya tapal batas hutan produksi terbatas (HPT) memberi kejelasan kepada masyarakat mengenai batas hutan yang harus di jaga ataupun dilindungi. masyarakat bisa leluasa berkebun diwilayah kebun yang tidak masuk kedalam wilayah batas hutan produksi terbatas (HPT). pemerintah daerah kabupaten Sinjai bekerja sama dengan perusahaan swasta untuk memanfaatkan wilayah kawasan hutan produksi terbatas(HPT) dengan cara memanfaatkan getah dari pohon pinus yang tentunya dapat membantu meningkatkan perekonomian masyarakat Desa Turungan Baji dan tentunya dapat menambah Pendapatan Asli Daerah (PAD)
Kabupaten Sinjai (pemberdayaan masyarakat).

\section{DAFTAR PUSTAKA}

Andi pradana pandi. 2016 Kebijakan Pemerintah Dalam Pengelolaan Dan Pelestarian Hutan Lindung Di Kecematan Tonra Kabupaten Bone. Skripsitidakditerbitkan.Mak assar.Unismuh Makassar.

Sumodiningrat Gunawan, 2012.Partisipasi masyarakat. Skripsitidakditerbitkan.Mak assar.Unismuh Makassar.

Arni, Muhammad, 2014Komunikasi Organisasi, PT. Bumi Aksara, Jakarta.

Cangara, Hafied, 2007.Pengantar Ilmu Komunikasi.Edisi Revisi. PT Raja Grafindo Persada Jakarta.

Erlina, Hasan. 2005. Komunikasih Pemerintahan. Aditama Jakarta.

Fajar Junaedi, 2012. Komunikasi politik. PT Gramedia. Jakarta.

Gidden Dan Lukes, 1984. Komunikasi Organisasi dalam Hubungan AntarKekuasaan dan Struktur. Rosdakarya. Bandung.

Romli Khomsahrial. 2011 Komunikasi Organisasi 
Lengkap. PT Grasindo, anggota ikapi, jakarta.

Mustari, $\quad$ Nuryanti. 2013 Implementasi Kebijakan Publik. Membumi publishing.

Suharyani. 2016 implementasi kebijakan pemerintah dalam pelestarian hutan lindung di kota

tarakan.Skripsitidakditerbitk an.Makassar.Unismuh

Makassar.

Syahdan T, Hasrul. 2015. KomunikasiPemerintahanDi nasPemudadanOlahragadal amPembinaanOrganisasiKe pemudaan di Kota Makassar.Skripsitidakditerb itkan.Makassar.Unismuh Makassar.
Undang-Undang Republik IndonesiaNomor 41tahu 1999 tentangkehutanan.

PP Nomor 6 Tahun 2007 tentang tata hutan dan penyusunan rencana pengelolaan hutan serta pemanfaatan hutan 